\title{
FAKTOR-FAKTOR YANG MEMPENGARUHI PENGGUNAAN KONTRASEPSI METODE OPERASI PRIA (MOP)
}

\author{
Desak Ketut Sugiartini ${ }^{*}$, Kade Ayu Suarmini ${ }^{2}$ \\ 1)Program Studi Diploma III Kebidanan, STIKes Buleleng \\ 2Program Studi Profesi Bidan, STIKes Buleleng \\ *Korespondensi Email : desakketutsugiartini@gmail.com
}

\section{ABSTRACT FACTORS AFFECTING THE USED OF MAN CONTRACEPTION OPERATION METHOD}

Background: The use of operation method of man contraception was still very little used, especially among husbands. Though the male operative method is very effective in terminating pregnancy. Operation method of man contraception was a method with a very high level of effectiveness. So the hoped that method of man contraception choice for couples if they intend to terminate the pregnancy. However, currently the use of method of man contraception is still very small, so it needs hard work to increase the use of method of man contraception.

Purpose:The purpose of this study was to determine the dominant factors associated with the use of MOP in Bebetin Village.

Methods:This type of research is quantitative research with the independent variables of education, knowledge, attitudes, family support and support from health workers. While the dependent variable is the use of the male operative method. The minimum sample size used was 68 respondents with the sampling technique used simple random sampling. This study used a questionnaire instrument in data collection. Then used enumerators assisted by posyandu and puskesmas in data collection. Analysis using chi-square then multivariate analysis used logistic regression.

Result:The results of the study found that there was a relationship between family support and the use of male operation method (AOR: $7.495 \% \mathrm{Cl}$ 1.6-33.6) and support from health professionals (AOR: $4.595 \% \mathrm{Cl} 1.0$ 20.1). Meanwhile education, attitudes and knowledge are not related to the use of male operation method in Bebetin Village.

Conclusion: The conclusion is that family support and health worker support are the dominant factors that husbands want to use male operation method

Suggestion: It is hoped that in the future support for family support and support for health workers will be increased while at the same time increasing the use of male operation method.

Keywords : male operative method; contraception; behavior

\section{ABSTRAK}

Latar Belakang: Penggunaan kontrasepsi mantap masih sangat sedikit digunakan khususnya pada kaum suami. Padahal metode operatif pria (MOP) sangat efektif untuk menghentikan kehamilan. Penggunaan MOP merupakan metode dengan tingkat efektifitas yang sangat tinggi. Sehingga harapannya kontrasepsi mantap menjadi pilihan pasangan jika berniat untuk menghentikan kehamilan. Namun saat ini penggunaan MOP masih sangat kecil dilakukan sehingga perlu kerja keras dalam meningkatkan penggunaan MOP.

Tujuan: Tujuan dari penelitian ini adalah mengetahui faktor dominan yang berhubungan dengan penggunaan MOP di Desa Bebetin.

Metode: Jenis penelitian yang dilakukan adalah penelitian kuantitatif dengan variabel independent pendidikan, pengetahuan, sikap, dukungan keluarga dan dukungan tenaga kesehatan. Sedangkan variabel dependen adalah penggunaan metode operatif pria. Besar sampel minimal yang digunakan adalah 68 responden dengan Teknik pengambilan sampel secara simple random sampling. Penelitian ini menggunakan instrument kuesioner dalam pengumpulan datanya. Kemudian menggunakan enumeroator dibantu posyandu dan puskesmas dalam pengumpulan data. Analisis menggunakan chisquare kemudian analisis multivariat menggunakan regresi logistik.

Hasil: Hasil penelitian menemukan bahwa terdapat hubungan dukungan keluarga dengan penggunaan MOP (AOR :7,4 95\% Cl 1,6-33,6) dan dukungan tenaga kesehatan (AOR :4,5 95\% Cl 1,0-20,1). Sedangkan pendidikan, sikap dan pengetahuan tidak berhubungan dengan penggunaan MOP di Desa Bebetin. 


\section{JKM (Jurnal Kebidanan Malahayati),Vol 7,No.2.April 2021, ISSN (Print) 2476-8944 ISSN (Online) 2579-762X, Hal 192-198}

Kesimpulan: Kesimpulannya bahwa dukungan keluarga dan dukungan tenaga kesehatan menjadi factor yang dominan suami mau menggunakan MOP.

Saran: Diharapkan kedepannya dukungan keluarga dan dukungan tenaga Kesehatan semakin ditingkatkan sekaligus meningkatkan penggunaan MOP

Kata kunci : metode operatif pria; kontrasepsi; perilaku

\section{PENDAHULUAN}

Indonesia merupakan negara dengan jumlah penduduk terbesar menempati posisi keempat didunia sebanyak 256 juta orang. Pertumbuhan penduduk Indonesia yang masih tinggi perlu dikendalikan, salah satunya dengan Program Keluarga Berencana (Ali,2009). Keluarga Berencana adalah salah satu yang sangat mempengaruhi perwujudan penduduk yang berkualitas. Masih cukup tingginya laju pertumbuhan penduduk disebabkan masih lebih tingginya tingkat kelahiran dibanding tingkat kematian. Pertumbuhan penduduk yang tinggi nmenyebabkan hasil-hasil pembangunan kurang bisa dirasakan masyarakat. Oleh karena itu upaya langsung untuk menurunkan tingkat kelahiran masih perlu ditingkatkan (Anggaraini, 2012).

Program KB di Indonesia sebelum dan sesudah ICPD-1994 mengalami perubahan yang nyata pada kurun 70-an sampai 90-an awal. Pelayanan Keluarga Berencana sangat menekankan pada aspek Demografis, yaitu pengendalian angka kelahiran (BKKBN, 2014). Apabila tidak dilakukan pengaturan kehamilan melalui program keluarga berencana (KB) akan mempengaruhi tingkat fertilitas di Indonesia.

Pelaksanaan program keluarga berencana dinyatakan dengan pemakaian alat/cara KB saat ini. Salah satu bagian dari program KB nasional adalah kontrasepsi mantap Vasektomi atau metode operatif pria (MOP) (Riset Kesehatan Dasar, 2018). Hasil laporan riset Kesehatan dasar (Riskesdas) mayoritas peserta KB baru saat ini, didominasi oleh peserta $\mathrm{KB}$ yang menggunakan Non Metode Kontrasepsi Jangka Panjang (Non MKJP). Sebaran penggunaan terbanyak yaitu pada suntik 3 bulan sebanyak 42,4\% (Kementrian Kesehatan RI, 2018).

Dari Data Badan Pusat Statistik Provinsi Bali tahun 2019 bahwa penggunaan kontrasepsi bervariasi dari berbagai Kabupaten. Penggunaan kontrasepsi MOP paling tinggi adalah Kota Denpasar (4601) selanjutnya di susul Kabupaten Buleleng (4584) (Dinas Statistik Kabupaten Buleleng, 2019), Tidak terjadi disparitas yang tinggi antara cakupan tertinggi dengan cakupan terendah di kabupaten/kota, hal ini menunjukkan telah terjadi pemerataan pelayanan $\mathrm{KB}$ di seluruh kabupaten/kota di Provinsi Bali Kabupaten/Kota dengan pencapaian cakupan peserta KB aktif tertinggi adalah Kabupaten Bangli (92,5\%), dan persentase peserta KB aktif terendah adalah Kabupaten Badung $(77,0 \%)$. Sedangkan Kabupaten Buleleng $(83,2 \%)$. Dilihat dari penggunaan MOP setelah melahirkan anak terakhir, Bali hanya mencapai nilai $0,1 \%$. Sedangkan penggunaan tertinggi masih pada suntik KB 3 bulan yaitu sebanyak 31,4\% (Riset Kesehatan Dasar, 2018).

Hasil laporan statistik Buleleng Tahun 2018 menemukan bahwa sebanyak 132.681 merupakan pasangan usia subur. Penggunaan kontrasepsi MKJP IUD di Buleleng Sebagian besar sudah tinggi yaitu 2.482 ibu. Sedangkan penggunaan Pil atau Non MKJP sebanyak 959 ibu (Dinas Statistik Kabupaten Buleleng, 2019). Jika dilihat lagi Kecamatan dengan penggunaan MKJP yang masih rendah salah satunya adalah Sawan. Penggunaan kontrasepsi mantap khususnya MOP masih sangat rendah yaitu hanya sebanyak $0,0024 \%$ dari jumlah pasangan usia subur di Sawan (Dinas Statistik Kabupaten Buleleng, 2019). Penggunaan MOP yang paling rendah di Kecamatan Sawan adalah Desa Bebetin. Padahal daerah ini merupakan lokasi bimbingan KB dan seharusnya pasangan usia subur lebih meningkatkan diri menggunaan metode jangka panjang.

Rendahnya keikutsertaan pria dalam penggunaan $\mathrm{KB}$ disebabkan karena sasaran $\mathrm{KB}$ Sebagian besar perempuan dan laki-laki kadang dipandang sebelah mata sehingga penyampaian informasi tidak banyak terkait kontrasepsi. Banyaknya factor pemicu dari rendahnya MOP juga dikarenakan perilaku individu yang berupa respon atau reaksi sangat bergantung dan meliputi Pendidikan terakhir, tingkat emosional dan suku (Irawan et al., 2013). Berdasarkan latar belakang diatas maka peneliti tertarik untuk melakukan penelitian dengan judul "Perilaku Penggunaan Kontrasepsi Metode Mantap (MOP) di Desa Bebetin". Tujuan penelitian ini adalah mengetahui factor perilaku yang paling dominan berhubungan dengan penggunaan kontrasepsi MOP di Desa Bebetin. 


\section{METODE}

Penelitian ini dilakukan di Desa Bebetin pada pasangan usia subur yang menggunakan KB. Penelitian ini merupakan penelitian kuantitatif dengan pendekatan secara cross sectional. Teknik pengumpulan data menggunakan kuesioner secara terstruktur yang sudah tervalidasi dengan jenis variable yang masuk ke dalam responden adalah sosiodemografi, pengetahuan, sikap, dukungan keluarga, dukungan tenaga Kesehatan, media informasi. Responden dilakukan pemilihan secara simple random sampling sampai mencapai sampel minimal yang diperlukan. Besar sampel minimal sesuai dengan rumus proporsi tunggal yang digunakan diperoleh responden sebanyak 68 responden. Penelitian ini menggunakan enumerator dalam pengumpulan datanya yaitu menggunakan tenaga petugas lapangan yaitu bidan atau perawat yang bertugas di Puskesmas, Posyandu ataupun pelayanan public di Desa Bebetin. Sebelum melakukan pengumpulan data kuesioner sudah dilakukan ujicoba dan penyamaan persepsi bersama dengan enumerator. Penelitian ini juga sudah mendapatkan ijin dari Dinas Perijinan Kabupaten Buleleng dan sudah dilakukan uji kelayakan etik di STIKES Buleleng. Hasil pengumpulan data di masukan kedalam tabulasi data melalui master tabel yang sudah dipersiapkan. Hasil kemudian dilakukan analisis secara univariat dan multivariat menggunakan software.

\section{HASIL}

Hasil penelitian ini diawali dengan melakukan analisis univariat terkait dengan variable yang masuk ke dalam penelitian ini. Tabel 1 menjelaskan terkait dengan analisis univariat variable yang masuk ke dalam penelitian dibawah.

Hasil analisis univariat menemukan bahwa rata-rata umur responden berada pada rentang umur 40 tahun dengan sebagian besar Pendidikan terkahir lulus SMA (60,3\%). Kemudian pekerjaanya adalah Sebagian besar sebagai pekerja swasta $(39,7 \%)$. Terkait dengan variable pengetahuan hampir sama antara pengetahuan responden yang baik dan cukup terkait dengan MOP. Kemudian Sebagian besar responden memiliki sikap yang cukup terhadap penggunaan MOP $(58,8 \%)$.
Responden juga melaporkan bahwa sebagian besar tidak didukung oleh keluarga $(57,6 \%)$ dan Sebagian besar didukung oleh tenaga Kesehatan (55,9\%). Kemudian analisis secara bivariat untuk menilai variable yang bisa masuk ke dalam analisis multivariat adalah terlihat pada table 2.

Tabel 1.

Analisis Univariat Variabel Penelitian

\begin{tabular}{lc}
\hline \multicolumn{1}{c}{ Variabel } & $\mathbf{f ( \% )}$ \\
\hline Umur (Mean \pm SD) & $39,16 \pm 6,4$ \\
\hline Pendidikan & \\
SD & $4(5,9)$ \\
SMP & $16(23,5)$ \\
SMA & $41(60,3)$ \\
PT & $7(10,3)$ \\
Pekerjaan & \\
Tidak bekerja & $1(1,5)$ \\
Petani & $9(13,2)$ \\
Pedagang & $26(38,2)$ \\
Swasta & $27(39,7)$ \\
PNS & $5(7,4)$ \\
Pengetahuan & \\
Baik & $34(50)$ \\
Cukup & $34(50)$ \\
Sikap & \\
Baik & $28(41,2)$ \\
Cukup & $40(58,8)$ \\
Dukungan Keluarga & \\
Mendukung & $29(42,6)$ \\
Tidak & $39(57,6)$ \\
Dukungan Nakes & \\
Mendukung & $38(55,9)$ \\
Tidak & $30(44,1)$ \\
Penggunaan MOP & \\
Menggunakan & $19(27,9)$ \\
Tidak & $49(72,1)$ \\
\hline & \\
&
\end{tabular}

Hasil analisis secara bivariat menemukan hasil bahwa variable yang bisa masuk ke dalam analisis multivariat adalah pengetahuan, sikap, dukungan keluarga dan dukungan tenaga kesehatan dengan nilai $p<0,05$. Kemudian variable ini dimasukkan ke dalam model analisis multivariat. Hasilnya dapat dilihat pada table 3 dibawah ini : 
JKM (Jurnal Kebidanan Malahayati),Vol 7,No.2.April 2021,

ISSN (Print) 2476-8944 ISSN (Online) 2579-762X, Hal 192-198

Tabel 2.

Analisis Bivariat Variabel Independen dengan penggunaan MOP

\begin{tabular}{lccc}
\hline \multicolumn{1}{c}{ Variabel } & \multicolumn{2}{c}{ Penggunaan MOP } & \multirow{2}{*}{ Nilai p } \\
\hline Pendidikan & $3(75,0)$ & $1(25,0)$ & \\
SD & $5(31,2)$ & $11(68,8)$ & \\
SMP & $11(26,8)$ & $30(73,2)$ & 0,06 \\
SMA & $0(0)$ & $7(100)$ & \\
PT & & & \\
Pekerjaan & $1(100)$ & $0(0)$ & \\
Tidak bekerja & $3(33,3)$ & $6(66,7)$ & \\
Petani & $7(26,9)$ & $19(73,1)$ & 0,57 \\
Pedagang & $7(25,9)$ & $20(74,1)$ & \\
Swasta & $1(20)$ & $4(80)$ & \\
PNS & & & \\
Pengetahuan & $14(41,2)$ & $20(58,8)$ & 0,015 \\
Baik & $5(14,7)$ & $29(85,3)$ & \\
Cukup & $12(42,9)$ & $16(57,1)$ & \\
Sikap & $7(17,5)$ & $33(82,5)$ & 0,022 \\
Baik & & & \\
Cukup & $15(51,7)$ & $14(48,3)$ & $<0,0001$ \\
Dukungan Keluarga & $4(10,3)$ & $35(89,7)$ & \\
Mendukung & & & \\
Tidak & $15(39,5)$ & $23(60,5)$ & 0,017 \\
Dukungan Nakes & $4(13,3)$ & $26(86,7)$ & \\
Mendukung & & & \\
Tidak & & & \\
\hline
\end{tabular}

Tabel 3.

Analisis Multivariat

\begin{tabular}{|c|c|c|c|c|}
\hline \multirow{2}{*}{ Variabel } & \multirow{2}{*}{ AOR } & \multirow{2}{*}{ Nilai $p$} & \multicolumn{2}{|c|}{$95 \% \mathrm{Cl}$} \\
\hline & & & Lower & Upper \\
\hline Pengetahuan baik & 1,7 & 0,4 & 0,4 & 7,5 \\
\hline Sikap baik & 1,1 & 0,9 & 0,2 & 4,5 \\
\hline Dukungan Keluarga & 7,4 & 0,01 & 1,6 & 33,6 \\
\hline Dukungan Nakes & 4,5 & 0,04 & 1,0 & 20,1 \\
\hline
\end{tabular}

Hasil analisis multivariat yang ditemukan adalah faktor perilaku dukungan keluarga yang mendukung penggunaan MOP 7,4 kali lebih meningkatkan suami menggunakan MOP hasil ini juga signifikan secara statistic (AOR :7,4 95\% Cl 1,6-33,6). Kemudian variable yang berhubungan lainnya adalah dukungan tenaga kesehatan, dimana dukungan nakes yang penuh 4,5 kali dapat meningkatkan penggunaan kondom (AOR :4,5 95\% $\mathrm{Cl}$ 1,0-20,1). Sedangkan variabel pengetahuan dan sikap tidak berhubungan secara statistik ketika dimasukkan ke dalam model multivariat dilihat dari nilai $p$ dan $95 \% \mathrm{Cl}$.

\section{PEMBAHASAN}

Hasil penelitian ini menemukan bahwa variabel yang berhubungan dengan penggunaan MOP adalah dukungan tenaga kesehatan dan dukungan keluarga. Kedua dukungan ini masuk ke dalam variabel perilaku yang berasal dari eksternal.

Menurut Bhumi Hasil analisis dari ujichisquare menunjukkan bahwa variabel yang memiliki pengaruh signifikan terhadap penggunaan kontrasepsi MOP di Kecamatan Sukodono Kabupaten Sidoarjo adalah variabel umur $(p=0,001)$ dan nilai $O R=18,2$. Variabel jumlah anak $(p=0,000)$ dan nilai $O R=29,8$. Variabel pengetahuan $(p=0,000)$ dan nilai $O R=21,1$. Variabel peran PLKB $(p=0,000)$ dan nilai $O R=12$. Variabel efek samping $(p=0,002)$ dan nilai $O R=0,4$. Variabel sosial 
budaya $(p=0,000)$ dan nilai $O R=3,9$. Variabel akses pelayanan $K B(p=0,002)$ dan nilai $O R=2,9$ dan variabel dukungan istri $(p=0,000)$ dan nilai $O R$ $=231,0$. Hasil analisis melalui uji regresi logistik berganda menunjukkan bahwa variabel yang paling berpengaruh signifikan terhadap penggunaan kontrasepsi MOP di Kecamatan Sukodono Kabupaten Sidoarjo adalah dukungan istri $(p=0,000)$.Menurut Safitri,2015 Para suami yang memiliki persepsi yang baik dan memiliki minat yang tinggi untuk menjadi akseptor MOP berjumlah 6 orang $(13,3 \%)$ dan sebaliknya sebagian besar responden yang memiliki persepsi yang kurang baik dan kurang berminat untuk menjadi akseptor MOP sebanyak 17 orang $(37,8 \%)$. Berdasarkan hasil uji Chi Square diperoleh nilai 0,002 $<0,05$.

\section{Dukungan Keluarga}

Hasil penelitian ini menemukan bahwa dukungan keluarga merupakan salah satu factor yang dominan berhubungan dengan penggunaan MOP. Hasil penelitian sebelumnya juga menemukan bahwa dukungan keluarga sangat berpengaruh terhadap peningkatan penggunaan MOP pada suami. (Purwanto, 2016). Dukungan keluarga merupakan salah satu bentuk hubungan interpersonal sehingga sesama anggota keluarga merasa ada suatu ikatan dan memberikan informasi. Selain itu penelitian sebelumnya juga menemukan hasil yang sama bahwa terdapat hubungan yang signifikan antara dukungan keluarga dengan penggunaan kontrasepsi (Wardiyah \& Utami, 2015). Dukungan keluarga menjadi satu factor yang penting agar suami mau menggunakan metode kontrasepsi pria. Keluarga akan mencarikan informasi dan memotivasi pria pentingnya penggunaan MOP. (Huda,2016)

Peran keluarga khususnya istri memiliki peran yang sangat tinggi untuk memotivasi suami. Dukungan keluarga dapat berupa dukungan social internal, dukungan istri, anak, saudara kandung, sampai pada orang tua (Ali 2010). Dukungan ini berlangsung sepanjang masa kehidupan. Sehingga seluruh keputusan dari dalam diri suami bergantung pada dukungan dari internal dan ekternal darinya (Suryati, 2014). Kontrasepsi Metode Operasi Pria (MOP) dilakukan suami dengan istri yang beresiko tinggi untuk hamil (Rahayu,2019).Motivasi instrinsik dan ekstrinsik pada akseptor lebih tinggi menggunakan MOP di bandingkan diperkotaan (Armini,2012). Hasil penelitian menunjukkan bahwa sebanyak 24 orang $(45,28 \%)$ responden mendapatkan motivasi pada kategori sedang dan sebanyak 35 orang $(66,04 \%)$ responden merupakan akseptor KB, dan hasil penelitian menunjukkan bahwa terdapat hubungan yang signifikan antara motivasi isteri dengan keikutsertaan suami dalam penggunaan kontrasepsi pria yang ditandai dengan nilai $p=0,001<a=0,05$ dengan $X 2$ hitung $=$ 14,992. (Yultri,2018). Suami diharapkan dapat meningkatkan kesadaran dirinya untuk ikut berpartisipasi aktif dalam program KB dengan metode apapun karena kesehatan reproduksi dan urusan KB bukan hanya tanggung jawab istri.(Putri,2014)

Menurut Puspitasari,2018 Hasil analisis chi square didapatkan nilai $\mathrm{p}$-value $=0,000<0,05$ maka $\mathrm{H} 1$ diterima, artinya ada hubungan pengetahuan dengan minat suami umur $30-50$ tahun dalam menggunakan KB Medis Operatif Pria (MOP).Berdasarkan hasil penelitian disimpulkan bahwa semakin baik pengetahuan suami tentang KB Medis Operatif Pria (MOP) maka semakin tinggi minat suami menggunakan KB Medis Operatif Pria (MOP). Diharapkan petugas kesehatan lebih aktif memberikan informasi tentang KB Medis Operatif Pria (MOP), sehingga dapat termotivasi menggunakan $\mathrm{KB}$ medis operatif pria (MOP).

Menurut Hardiyati, 2015 Sebagian besar tingkat pengetahuan suami tentang pengertian MOP di Puskesmas Sanden kategori baik $(61,2 \%)$, tentang keuntungan MOP kategori baik $(52,2 \%)$, kerugian MOP kategori cukup $(37,5 \%)$, tentang syaratsyarat MOP kategori baik $(71,6 \%)$, tentang indikasi dan kontra indikasi MOP kategori baik $(53,7 \%)$, tentang efektifitas MOP kategori baik $(61,2 \%)$, tentang perawatan MOP kategori baik $(44,8 \%)$, tentang komplikasi MOP kategori baik $(44,8 \%)$. Sebagian besar responden berumur 40 - 49 tahun $(62,7 \%)$, dengan pendidikan terakhir SMA $(40,3 \%)$, dan status pekerjaan sebagai petani $(49,3 \%)$.Menurut Zubaidah,2019 Bagi suami pasangan usia subur di Kelurahan Giwangan Umbulharjo Yogyakarta diharapkan lebih aktif dalam meningkatkan informasi yang berkaitan dengan kontrasepsi MOP.

Menurut Wisudawati,2018 Pengambilan keputusan suami dalam penggunaan MOP berdasarkan pendidikan sebagian besar berpendidikan rendah, pengambilan keputusan suami dalam penggunaan MOP berdasarkan pengetahuan sebagian besar memiliki pengetahuan tinggi, pengambilan keputusan suami dalam penggunaan MOP berdasarkan dukungan keluarga sebagian besar mendapat dukungan. Ada hubungan persepsi dan 


\section{JKM (Jurnal Kebidanan Malahayati),Vol 7,No.2.April 2021, \\ ISSN (Print) 2476-8944 ISSN (Online) 2579-762X, Hal 192-198}

pengetahuan suami dengan keikutsertaan menjadi akseptor KB MOP. Diharapkan bagi bidan, dokter spesialis obgyn dan tenaga medis lainnya untuk memberikan penyuluhan kepada pasangan usia subur tentang KB MOP, keuntungan dan kekurangan ber KB MOP sehingga meningkatkan terciptanya keluarga yang sehat dan berkualitas.(Sirait,2019). Terdapat faktor yang memengaruhi keikutsertaan suami menjadi akseptor MOP, faktor pengetahuan yang sangat besar pengaruhnya terhadap keikutsertaan suami menjadi akseptor MOP karena semakin dekatnya nilai $p 0,000$ dengan nilai constant $p 0,000$ semakin besar pengaruhnya terhadap keikutsertaan menjadi akseptor KB MOP.(Simbolon 2018). Dukungan istri pada kontrasepsi Metode Operatif Pria (MOP) mayoritas dukungan baik yaitu sebanyak 54 reponden (55,1\%). Menurut Sukmawardhanni,2017 Mayoritas Dukungan informasional istri dukungan kurang yaitu sebanyak 57 reponden $(58,2 \%)$. Dukungan penilaian istri sebanyak 58 responden $(59.2 \%)$ dikategorikan dalam dukungan baik. dukungan instrumental dan dukungan emosional istri yaitu masing-masing 49 responden $(50 \%)$ untuk dukungan baik dan kurang. Simpulan: Dukungan istri pada kontrasepsi Metode Operatif Pria (MOP) di wilayah kerja Puskesmas Jetis 1 Bantul memiliki dukungan baik sebanyak 54 responden (55.1\%). Persentase terbesar suami terdapat pada persepsi suami baik $(32,4 \%)$, KIE kurang $(75,0 \%)$, dan kesediaan MOP kurang (47,1\%). (Azizah,2016)

\section{Dukungan Tenaga Kesehatan}

Selain dukungan dari keluarga terdapat dukungan yang tidak kalah pentingnya lagi dan berhubungan untuk meningkatkan penggunaan MOP yaitu dukungan dari tenaga kesehatan. Hasil penelitian sebelumnya di Surakarta menemukan hasil yang sama bahwa terdapat hubungan dukungan tenaga kesehatan dengan peningkatan penggunaan MOP pada suami pasangan usia subur (Muyassaroh et al., 2018).

Dukungan ini dimulai dari pemberian konseling, dimana konseling merupakan salah satu aspek yang sangat penting dalam pelayanan kesehatan yang diberikan tenaga kesehatan kepada klien/pasiennya. Memberikan konseling sama artinya dengan memberikan sebuah informasi dan pilihan yang bermanfaat bagi pasien sampai pada memilih dan melaksanakan kontrasepsi sesuai dengan pilihannya. Konseling secara langsung menyebabkan interaksi antara petugas kesehatan dengan klien sehingga dapat menciptakan hubungan atau interaksi yang posistif. Namun jika sebaliknya tenaga kesehatan tidak memberikan penjelasan dengan baik dan tergesagesa maka akan sangat sulit untuk menyampaikan pesan dan informasi untuk kesehatan klien (Muyassaroh et al., 2018).

Menurut Prihastuti,2009 suami dan pasangan terus meningkatkan motivasi intrinsik,dan bidan atau petugas atau pemberi pelayanan KB yang lain terus berusaha meningkatkan motivasi suami terhadap KB sehingga akseptor vasektomi meningkat dan taraf kesehatan perempuan meningkat.

Jika dilihat dari variabel lainnya yang tidak berhubungan adalah pengetahuan dan sikap. Hal ini berbeda ditemukan pada penelitian sebelumnya di Sumbawa bahwa pengetahuan dan sikap berhubungan dengan perilaku penggunaan MOP pada Pria di Sumbawa (Wardani et al., 2020). Hal ini disebabkan informasi yang diterima dapat meningkatkan pengetahuan suami dan sikap suami yang positif terhadap penggunaan kontrasepsi. Tidak seharusnya wanita saja yang menggunakan kontrasepsi tetapi suami juga ikut andil dalam penjarangan kehamilan. Namun pada hasil penelitian ini tidak ditemukan hasil yang sejalan. Hal ini dikarenakan belum tentu dengan pengetahuan yang sudah baik dan sikap yang positif terhadap MOP pria atau suami mau menggunakan MOP. Memang sangat kecil hasil penelitian yang membuktikan pengetahuan dan sikap tidak berhubungan dengan penggunaan kontrasepsi. Namun jika dilihat bahwa reaksi atau stimulus terhadap seseorang sangat dipengaruhi beberapa faktor salah satunya sifat bawaan, tingkat emosional dan suku (Irawan et al., 2013). Hal inilah yang berperan penting dalam proses pemilihan kontrasepsi. Banyak pria yang tahu dan paham terkait dengan MOP namun takut, tidak mau sulit dalam proses penggunaan kontrasepsi. Sehingga peran dukungan keluarga dan tenaga kesehatan menjadi faktor yang paling utama penggunaan MOP pada suami di Bebetin.

Hasil Penelitian Widyawati,2019 terdapat hubungan antara pengetahuan dengan motivasi menjadi akseptor KB MOP. Kesimpulan dari penelitian ini yaitu pengetahuan yang kurang tentang KB MOP dapat mempengaruhi motivasi seseorang untuk menjadi akseptor KB tersebut. Saran kepada tenaga kesehatan untuk lebih meningkatkan lagi dalam memberikan informasi tentang metode KB MOP kepada masyarakat, sehingga masyarakat dapat mengetahui lebih lanjut tentang KB MOP. 


\section{SIMPULAN}

Faktor yang paling dominan terhadap penggunaan kontrasepsi MOP adalah dukungan keluarga dan dukungan tenaga kesehatan. Sedangkan pengetahuan yang baik dan sikap tidak berhubungan secara signifikan pada analisis yang dilakukan.

\section{SARAN}

Diharapkan petugas kesehatan dan keluarga selalu memberikan dukungan terkait penggunaan kontrasepsi pria. Karena faktor ini menjadi pemicu terbesar peningkatan kontrasepsi MOP. Selain itu konseling dari tenaga kesehatan terkait pemilihan KB MOP juga perlu ditingkatkan sehingga tidak hanya meningkatkan pengetahuan dan sikap tetapi memilih dan menggunakan MOP sebagai kontrasepsi pilihan untuk menghentikan kehamilan.

\section{DAFTAR PUSTAKA}

Ali, M. (2009). Pendidikan untuk pembangunan nasional: menuju bangsa Indonesia yang mandiri dan berdaya saing tinggi. Grasindo.

Ali, H. Z., \& SKM, M. (2010). Pengantar keperawatan keluarga. EGC.

Anggaraini, Y. (2012). Pelayanan Keluarga Berencana. Rohima Press.

Armini, N. W. (2012). Motivasi Pria Pedesaan Dan Perkotaan Menjadi Akseptor Metode Operasi Pria (MOP) Di Bali. Jurnal Skala Husada, 73.

Azizah, Y. N., Nugroho, D., \& Dharminto, D. (2016). HUBUNGAN PERSEPSI DAN KIE DENGAN KESEDIAAN MOP DI KECAMATAN PADURESO KABUPATEN KEBUMEN TRIWULAN I TAHUN 2016. Jurnal Kesehatan Masyarakat (e-Journal), 4(3), 36-49.

Bhumi, S. FAKTOR-FAKTOR YANG MEMPENGARUHI PENGGUNAAN KONTRASEPSI METODE OPERASI PRIA (MOP) DI KECAMATAN SUKODONO KABUPATEN SIDOARJO.

BKKBN. (2014). Buku Panduan Praktis Pelayanan Kontrasepsi (3rd ed.). PT Bina Pustaka.

Dinas Statistik Kabupaten Buleleng. (2019). Statistik Sosial Daerah Kabupaten Buleleng 2019.

Hardiyati, A. (2015). GAMBARAN TINGKAT PENGETAHUAN SUAMI TENTANG ALAT KONTRASEPSI MOP DI PUSKESMAS SANDEN BANTUL YOGYAKARTA (Doctoral dissertation, STIKES Jenderal A. Yani Yogyakarta).

Huda, A., Wardani, R. S., \& Purwanti, I. A. (2016). FAKTOR-FAKTOR YANG BERHUBUNGAN
DENGAN KEJADIAN UNMET NEED KELUARGA BERENCANA DI PUSKESMAS BANDARHARJO KECAMATAN SEMARANG UTARA (Studi di Kelurahan Dadapsari) (Doctoral dissertation, UNIMUS).

Irawan, D., Keloko, A. B., \& Syahrial, E. (2013). Perilaku Suami Terhadap Alat Kontrasepsi Pria (Vasektomi) Di Desa Ujung Pulo Cut Kecamatan Bakongan Timur Kabupaten Aceh Selatan Tahun 2013 (Issue 4).

Kementrian Kesehatan RI. (2018). Riset Kesehatan Dasar 2018.

Muyassaroh, Y., Astirin, O. P., \& Hanim, D. (2018). Hubungan Antara Pengetahuan Ibu Tentang Kontrasepsi, Jumlah Anak, Dukungan Suami dan Konseling Tenaga Kesehatan Dengan Pemakaian Metode Kontrasepsi Jangka Panjang di Kabupaten Blora. https://doi.org/10.15900/j.cnki.zylf1995.2018. 02.001

Prihastuti, A. F., \& Nawangsih, U. H. E. (2009). GAMBARAN MOTIVASI SUAMI TERHADAP KB VASEKTOMI DI WILAYAH KERJA PUSKESMAS KALASAN SLEMAN YOGYAKARTA TAHUN 2009 (Doctoral dissertation, Universitas' Aisyiyah Yogyakarta).

Purwanto, A. H. (2016). Faktor Determinan Perilaku Keluarga Berencana (KB) Dengan Metode Operasi Pria (MOP) di Kecamatan Jenawi Kabupaten Karanganyar. In Universitas Muhammadiyah Surakarta.

Puspitasari, B., \& Puspitasari, D. (2018). HUBUNGAN PENGETAHUAN DENGAN MINAT SUAMI UMUR 30-50 TAHUN DALAM MENGGUNAKAN KB MEDIS OPERATIF PRIA (MOP). JURNAL KEBIDANAN, 7(1).

Putri, M. A. S., Hariyadi, S., \& Prihastuty, R. (2014). Motivasi suami mengikuti program kb dengan metode kontrasepsi mantap (vasektomi). Developmental and Clinical Psychology, 3(1).

Rahayu, A., Wahyuni, W., \& Sri Wahyuni, E. (2019). GAMBARAN SIKAP DAN MOTIVASI SUAMI TENTANG KONTRASEPSI METODE OPERASI PRIA DI WILAYAH KERJA PUSKESMAS SAMBIREJO KABUPATEN SRAGEN (Doctoral dissertation, STIKES'AISYIYAH SURAKARTA).

Riset Kesehatan Dasar. (2018). Laporan Nasional Riskesdas 2018. http://labdata.litbang.kemkes.go.id/images/d ownload/laporan/RKD/2018/Laporan_Nasion 
JKM (Jurnal Kebidanan Malahayati),Vol 7,No.2.April 2021,

ISSN (Print) 2476-8944 ISSN (Online) 2579-762X, Hal 192-198

al_RKD2018_FINAL.pdf

Safitri, R. T., \& Mutika, W. T. (2015). Hubungan Persepsi Suami dengan Minat Suami menjadi Akseptor Kontrasepsi MOP (Metode Operatif Pria) di Dusun Krodan Depok Sleman (Doctoral dissertation, STIKES'Aisyiyah Yogyakarta).

SIRAIT, S. (2019). HUBUNGAN PERSEPSI DAN PENGETAHUAN SUAMI DENGAN KEIKUTSERTAAN MENJADI AKSEPTOR KB MOP DI RSUD. DR. H. KUMPULAN PANE TEBING TINGGI TAHUN 2018.

SIMBOLON, W. A. (2018). FAKTOR YANG MEMENGARUHI KEIKUTSERTAAN SUAMI MENJADI AKSEPTOR MOP (METODE OPERATIF PRIA) DI DESA MARJANJI KECAMATAN SIPISPIS KABUPATEN SERDANG BEDAGAI TAHUN 2018 (Doctoral dissertation, INSTITUT KESEHATAN HELVETIA).

Sukmawardani, P. U. (2017). GAMBARAN DUKUNGAN ISTRI PADA SUAMI DALAM PENGGUNAAN KONTRASEPSI METODE OPERATIF PRIA (MOP) DI WILAYAH KERJA PUSKESMAS JETIS 1 BANTUL.

Suryati, E. (2014). Pengaruh Pengetahuan Ibu, Sikap Ibu dan Dukungan Keluarga Terhadap Perilaku Penggunaan KB Suntik 3 Bulan Pada Pasangan Usia Subur di Puskesmas Cibeber KOta Cilegon Tahun 2013.

Wardani, S., Latifah, U., \& Lestari, Y. (2020). Hubungan Tingkat Pengetahuan dengan Penggunaan MOP Untuk Melakukan KB Pria Di Desa Baru Tahan Kecamatan Moyo Utara. Jurnal Kesehatan Dan Sains, 3(2), 34-45.

Wardiyah, A., \& Utami, V. W. (2015). Faktor-Faktor yang Berhubungan Dengan Penggunaan Kontrasepsi MOP (Medis Operasi Pria) Di Kecamatan Tanjung Karang Timur Tahun 2011. Jurnal Kesehatan Holistik, 9 (1)(1), 22-26.

Widyawati, E., \& Lestari, R. D. (2019). Hubungan Pengetahuan Suami dengan Motivasi Menjadi Akseptor KB MOP di Dusun Jabang Desa Sidomulyo Kecamatan Semen Kabupaten Kediri. Jurnal Kesehatan Ibu Dan Anak (Mother and Child Medical Science Journal), 4(2), 037-048.

Wisudawati, W. (2018). Analisis Pengambilan Keputusan Suami Dalam Penggunaan Metoda Operasi Pria (MOP) Di Wilayah Kecamatan Neglasari Tangerang. Jurnal IImiah Kesehatan Delima, 2(2), 68-78.

Yultri Yanti A Doro, P. (2018). HUBUNGAN MOTIVASI ISTERI DENGAN KEIKUTSERTAAN SUAMI DALAM PENGGUNAAN KONTRASEPSI PRIA DI KELURAHAN WUNDULAKO KECAMATAN WUNDULAKO KABUPATEN KOLAKA TAHUN 2018 (Doctoral dissertation, Poltekkes Kemenkes Kendari).

Zubaidah, S. R. (2019). Hubungan Tingkat Pengetahuan Dengan Minat Penggunaan Kontrasepsi Mop Pada Suami Pasangan Usia Subur Di Giwangan Umbulharjo Kota Yogyakarta (Doctoral dissertation, Universitas' Aisyiyah Yogyakarta). 